\title{
THRB Gene
}

National Cancer Institute

\section{Source}

National Cancer Institute. THRB Gene. NCI Thesaurus. Code C18377.

This gene plays a role in receptor signaling and regulation of transcription. It is involved in inner ear development and color vision. 